\title{
Analisis Faktor-Faktor Yang Mempengaruhi Turnover Intention Agent di PT AIA Cabang X Malang
}

\author{
Lidia Halim*, Kevin Antolis \\ Fakultas Ekonomi dan Bisnis, Program Studi Manajemen, Universitas Ma Chung, Malang, Indonesia \\ Email: 1,*lidia.halim@machung.ac.id, ${ }^{2}$ antoliskevin17@gmail.com \\ Email Penulis Korespondensi: lidia.halim@machung.ac.id \\ Submitted: 16 Februari 2021; Accepted: 27 Februari 2021; Published: 28 Februari 2021
}

\begin{abstract}
Abstrak-Turnover intention merupakan persoalan yang sering dihadapi pada perusahaan dan karyawan. Turnover intention perlu dijadikan pusat perhatikan karena tingginya turnover intention dapat mengganggu aktivitas dan produktivitas perusahaan dan karyawan. Pada perusahaan PT AIA Cabang X Malang ada beberapa faktor yang menyebabkan turnover intention. Tujuan penelitian ini untuk mengetahui faktor-faktor apa saja yang mempengaruhi turnover intention agent di PT AIA Cabang X Malang. Penelitian ini merupakan penelitian kuantitatif dengan pendekatan konfirmatori (confirmatory research). Teknik analisis data yang digunakan adalah analisis faktor. Responden yang diteliti dalam penelitian ini sebanyak 202 orang dari 202 orang populasi di PT AIA Cabang X Malang. Hasil penelitian ini menunjukkan bahwa seluruh variabel work life balance, personality-job fit, stres kerja, hubungan karyawan, kompensasi, lingkungan kerja fisik, kepuasan kerja, budaya organisasi, pengembangan karir, dan komitmen organisasi terkonfirmasi mempengaruhi turnover intention agent di PT AIA Cabang X Malang. Variabel yang paling berpengaruh signifikan terhadap turnover intention agent di PT AIA Cabang X Malang yaitu komitmen organisasi dan variabel yang berpengaruhi tetapi kurang signifikan yaitu stres kerja.
\end{abstract}

\section{Kata Kunci: Asuransi, Agent, Turnover Intention, Komitmen Organisasi, Stress Kerja}

Abstract-Turnover intention is a problem that is often faced by companies and employees. Turnover intention needs to be a center of attention because high turnover intention can disrupt the activities and productivity of companies and employees. In PT AIA Branch $\mathrm{X}$ Malang there are several factors that cause turnover intention. The purpose of this study was to find out what factors influenced the turnover intention of the agent at PT AIA Branch X Malang. This research was a quantitative study with a confirmatory research approach. The data analysis technique used was factor analysis. Respondents studied in this study were 202 people from 202 population in PT AIA Branch X Malang. The results of this study indicated that all work life balance variables, personality-job fit, work stress, employee relations, compensation, physical work environment, job satisfaction, organizational culture, career development, and organizational commitment affect the turnover intention of the agents at PT AIA Branch X Malang. The variable that has the most significant influence on turnover intention of the agents ata PT AIA Branch X Malang was organizational commitment and the variable that influence less significant namely work stress.

Keywords: Agent, Insurance, Turnover Intention, Organizational Commitment, Work Stress

\section{PENDAHULUAN}

Sumber daya manusia yang berkualitas dan kompeten adalah keinginan semua perusahaan. Tidak hanya mendapatkan sumber daya, tetapi juga bagaimana cara agar perusahaan dapat mempertahankan karyawan potensial agar dapat bertahan selama mungkin di perusahaan. Sumber daya manusia dalam suatu perusahaan bukan hanya sebagai alat pada kegiatan produksi perusahaan, tetapi memiliki peran penting dalam kegiatan produksi perusahaan. Manajemen sumber daya manusia adalah karyawan yang telah siap, mampu dan siaga dalam mencapai tujuan-tujuan yang diberikan oleh organisasi. Sebagaimana dikemukakan bahwa dimensi pokok dari sumber daya manusia adalah perlakuan kepada seseorang yang mana nantinya akan menentukan kualitas dan kapabilitasnya (Sutrisno 2019).

Sumber daya manusia di dalam perusahaan perlu dikelola secara profesional, karena kunci utama berkembangnya suatu perusahaan dapat dilihat dari sumber daya manusia yang produktif (Mangkunegara and Prabu 2009). Adanya pengelolaan sumber daya manusia yang baik dan profesional dapat dijadikan faktor penentu keberhasilan dan kesuksesan suatu perusahaan. Untuk mewujudkan tujuan perusahaan, perusahaan harus memanfaatkan sumber daya manusia yang ada seoptimal mungkin.

Kualitas dari sumber daya manusia itu sendiri harus selalu ditingkatkan demi mencapai tujuan dari perusahaan. Sumber daya manusia yang dibutuhkan perusahaan harus memiliki kompetensi dan kinerja terbaik yang didapatkan melalui proses panjang yang dilakukan oleh perusahaan. Perusahaan pun akan mengembangkan sumber daya manusia yang ada menjadi lebih baik dan lebih produktif.

Karyawan merupakan element yang penting bagi perusahaan karena kinerja karyawan akan berdampak pada kegiatan operasional perusahaan. Apabila kinerja karyawan rendah, maka akan menjadi hambatan bagi perusahaan dalam mencapai tujuan perusahaan. Perusahaan perlu memperhatikan karyawan agar dapat berkontribusi dengan baik terhadap perusahaan. Karyawan yang tidak mendapatkan perhatian yang baik dari perusahaan dan kebutuhan karyawan tidak terpuaskan, bisa saja karyawan akan memilih untuk meninggalkan perusahaan. Jika manajemen perusahaan dapat mengelola dan menggunakan karyawan yang ada secara optimal, maka karyawan pun akan merasa termotivasi dan memiliki semangat kerja yang tinggi sehingga produktivitas karyawan pun akan meningkat.

Lisan menjelaskan bahwa turnover adalah kondisi di mana seorang karyawan berhenti bekerja secara sukarela atau pindah kerja ke perusahaan lain (Lisan 2016). Jika dilihat dari segi ekonomi, tentunya perusahaan akan mengeluarkan cost yang cukup besar karena perusahaan akan sering melakukan recruitment, pelatihan dan faktor-faktor lain yang mempengaruhi suasana kerja menjadi kurang menyenangkan. Karyawan merupakan aset utama suatu perusahaan untuk 
bersaing dalam bisnis, sehingga perusahaan diharapkan dapat mencegah karyawan untuk keluar dengan memperhatikan beberapa faktor yang menjadi pemicu karyawan berkeinginan untuk keluar dari perusahaan.

Sari mengatakan bahwa turnover intention adalah intensitas dari keinginan karyawan untuk keluar dari perusahaan, banyak alasan yang menyebabkan timbulnya turnover intention ini dan diantaranya adalah keinginan untuk mendapatkan pekerjaan yang lebih baik (Sari 2015). Turnover Intention karyawan yang tinggi akan membawa pengaruh yang kurang baik terhadap perusahaan, baik dari segi biaya maupun dari segi hilangnya waktu dan kesempatan untuk memanfaatkan peluang. Turnover intention yang tinggi juga mengakibatkan organisasi tidak efektif karena dapat mengakibatkan perusahaan kehilangan karyawan yang berpengalaman dan perlu melatih kembali karyawan baru. Dari penjelasan di atas dapat disimpulkan bahwa turnover intention adalah keinginan berpindah yang menggambarkan pikiran karyawan untuk keluar, mencari pekerjaan di tempat lain, serta keinginan karyawan untuk meninggalkan organisasi.

Turnover intention yang lebih tinggi harus mendapatkan perhatian yang lebih dari perusahaan sebab dapat menganggu kegiatan perusahaan seperti kinerja team dan juga nantinya dapat meningkatkan biaya seperti rekrutmen, wawancara, dan tes. Turnover intention yang lebih tinggi pada perusahaan maka lebih sering perusahaan mengalami pergantian atau perputaran karyawan, dan biaya-biaya yang dikeluarkan perusahaan jauh lebih besar lagi. Turnover intention yang rendah dapat memperkecil perputaran karyawan serta biaya-biaya yang dikeluarkan.

Menurut data yang dilansir (Indonesia n.d.) mereka memprediksi bahwa sebanyak $72 \%$ responden di Indonesia pada tahun 2015 memiliki minat untuk berganti pekerjaan pada tahun 2016. Berikut gambar mengenai pernyataan dari Michael Page Indonesia.

\section{Employee Turnover in the Next 12 Months}

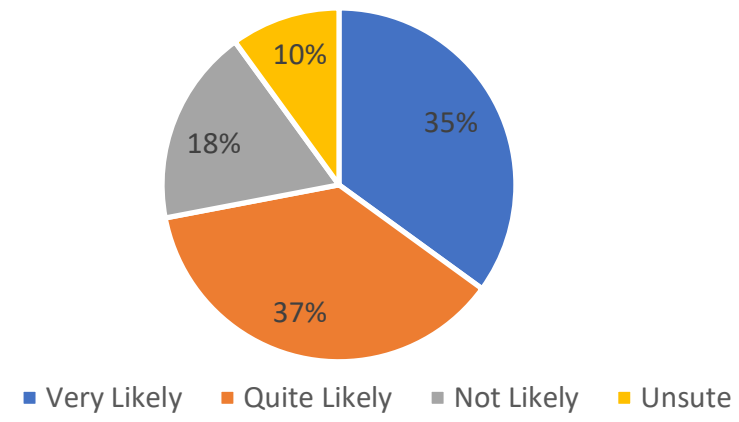

Gambar 1. Trend Turnover Intention di Indonesia Pada Tahun 2016 Sumber : Michael Page Indonesia, (2015)

Dari data di atas bisa dilihat bahwa 35\% mengatakan bahwa mereka sangat mungkin untuk berpindah pekerjaan nantinya, 37\% mengatakan mungkin akan pindah, 18\% mengatakan bahwa tidak mungkin untuk pindah dan $10 \%$ tidak memberikan pendapat. Tingginya tingkat turnover karyawan akan membuat perusahaan merasa dirugikan jika banyaknya karyawan yang sering keluar dari perusahaan.

Perusahaan asuransi merupakan perusahaan dengan jumlah karyawan yang banyak, baik agent maupun karyawan yang menjadi staff. Perusahaan asuransi terkadang menjadi bahan untuk seseorang mencoba-coba pekerjaan di bidang pemasaran, sehingga banyaknya karyawan yang masuk dan keluar. Perusahaan asuransi merupakan perusahaan yang banyak mempekerjakan karyawan atau yang biasa disebut dengan agent. Jumlah agent asuransi yang masuk dan keluar dalam satu perusahaan terkadang sangat besar. Tidak menutup kemungkinan jika tingkat turnover di perusahaan asuransi sangat tinggi, karena pekerjaan para agent yang dapat dikatakan freelance.

PT AIA Cabang X Malang merupakan salah satu perusahaan yang bergerak di bidang asuransi. Tingkat turnover pada perusahaan yang bergerak di bidang asuransi bisa dikatakan cukup tinggi. Hal ini dapat dilihat dari data turnover agent pada perusahaan PT AIA Cabang X Malang. Berikut penjelasan lebih dalam dari Tabel 1 mengenai jumlah agent asuransi yang masuk dan keluar PT AIA Cabang X Malang dari tahun 2014-2018.

Tabel 1. Jumlah Agent Masuk dan Keluar PT AIA

\begin{tabular}{ccccc}
\hline Tahun & $\begin{array}{c}\text { Jumlah Agent } \\
\text { Awal Tahun }\end{array}$ & Masuk & Keluar & $\begin{array}{c}\text { Jumlah Agent } \\
\text { Akhir Tahun }\end{array}$ \\
\hline 2014 & 300 & 6 & 60 & 246 \\
2015 & 246 & 14 & 57 & 203 \\
2016 & 203 & 14 & 7 & 210 \\
2017 & 210 & 34 & 25 & 219 \\
2018 & 219 & 13 & 30 & 202 \\
Rata-Rata Jumlah Agent & $\mathbf{1 6}$ & $\mathbf{3 3}$ & \\
\hline
\end{tabular}




\section{Jumlah Agent Masuk dan Keluar PT AIA Cabang X Malang}

100

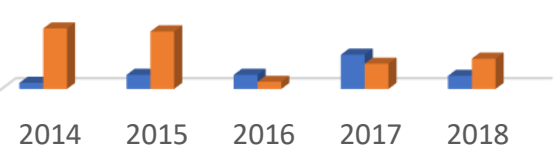

- In $n$ Out

Gambar 2. Jumlah Karyawan masuk dan keluar PT AIA Cabang X Malang Sumber : PT AIA (2018)

Dari data di atas bisa dilihat bahwa jumlah agent yang masuk dan agent yang keluar tidaklah seimbang. Setiap tahunnya jumlah agent yang keluar selalu lebih banyak jika dibandingkan dengan jumlah agent yang masuk. Hal ini dapat dilihat dari rata-rata tiap tahunnya, yang mana setiap tahunnya rata-rata agent yang keluar sebanyak 33 dan agent yang masuk sebanyak 16. Menjadikan ini sebagai salah satu masalah yang serius bagi perusahaan. Apabila hal ini terus terjadi dalam suatu perusahaan, maka dapat menggangu efektivitas jalannya perusahaan serta dapat menimbulkan kerugiaan bagi perusahaan.

Menurut (Wahyuni, Zaika, and Anwar 2015) faktor yang diindikasikan mempengaruhi turnover intention dari suatu perusahaan yaitu hubungan karyawan dan kompensasi. Sedangkan menurut (Etnaningtiyas 2011) yaitu personalityjob fit, pendidikan, usia, dan jenis kelamin. Sedangkan menurut (Firdaus 2017) turnover intention dipengaruhi oleh kepuasan kerja dan komitmen organisasi. Sedangkan menurut(Ramasari and Wahyuningtyas 2014) ada 4 faktor yang mempengaruhi turnover intention di suatu perusahaan, yaitu stres kerja, kepuasan kerja, pengembangan karir, dan komitmen organisasi. Sedangkan menurut (Tedjo 2016) faktor yang dapat mempengaruhi turnover intention adalah stres kerja, hubungan karyawan, kompensasi, lingkungan kerja, kepuasan kerja, budaya organisasi, dan komitmen organisasi.

Berdasarkan penelitian terdahulu di atas, maka peneliti melakukan pra survey kepada manajer dan 2 orang perwakilan karyawan di PT AIA dengan metode wawancara. Dari hasil wawancara yang dilakukan, dapat diketahui bahwa terdapat beberapa faktor yang diindikasikan dapat mempengaruhi turnover intention karyawan PT AIA Cabang X Malang, yaitu komitmen organisasi, budaya organisasi, kepuasan kerja, lingkungan kerja, kompensasi, hubungan karyawan, stres kerja, dan work life balance. Berdasarkan hasil uraian di atas, maka tujuan dari penelitian ini adalah mengetahui dan menganalisis faktor-faktor apa saja yang mempengaruhi turnover intention agent di PT AIA Cabang X Malang.

\section{KERANGKA TEORI}

\subsection{Kerangka Penelitian}

Penelitian ini didasarkan dari tingginya tingkat turnover agent pada perusahaan PT AIA Cabang X Malang dimana setiap tahunnya jumlah agent yang keluar selalu lebih banyak jika dibandingkan dengan jumlah agent yang masuk. Peneliti ingin mengetahui dari berbagai faktor yang mempengaruhi turnover intention agent di PT AIA Cabang X Malang antara lain dengan menggunakan confirmatory factor analysis (CFA) untuk mengetahui faktor yang memiliki peran terbesar dalam mempengaruhi turnover intention karyawan PT AIA Cabang X Malang.

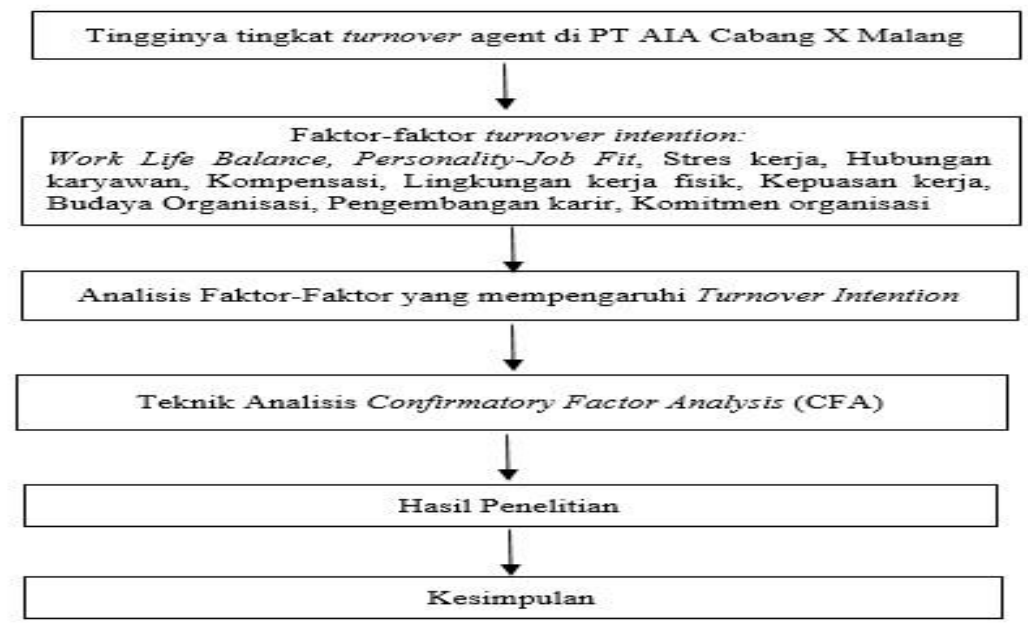

Gambar 3. Kerangka Penelitian 


\section{METODOLOGI PENELITIAN}

Jenis penelitian yang digunakan adalah penelitian kuantitatif dengan pendekatan penelitian konfirmatori. (Ghozali 2006) menjelaskan penelitian konfirmatori mampu menganalisis hubungan antara satu variabel dengan variabel lainnya atau bagaimana satu variabel memengaruhi variabel lainnya untuk mengkonfirmasi teori yang sudah ada. Penelitian ini bertujuan untuk mengetahui faktor apa saja yang mempengaruhi turnover intention agent di PT AIA Cabang X Malang. Variabel penelitian yang digunakan dalam penelitian ini adalah variabel independen. (Darmadi 2013) mengungkapkan variabel penelitian merupakan batasan pendefinisian dari serangkaian variabel yang digunakan dalam penulisan penelitian, dengan maksud menghindari kemungkinan adanya makna ganda, sekaligus mendefinisikan variabel-variabel sampai dengan kemungkinan pengukuran dan cara pengukurannya, sehingga itu variabel penelitian merupakan penjabaran atau penjelasan mengenai variabel-variabel yang ada, dan juga merupakan penjelasan-penjelasan mengenai variabel yang menjadi kajian dalam penelitian tersebut. Dalam penelitian ini, variabel independennya adalah faktor-faktor yang mempengaruhi turnover intention. Berikut ini merupakan definisi operasional yang ditentukan oleh peneliti antara lain:

Tabel 2. Definisi Operasional Variabel

\begin{tabular}{|c|c|c|c|}
\hline Jenis Variabel & Definisi & Indikator & Skala \\
\hline Work Life Balance & $\begin{array}{l}\text { Dapat membantu karyawan untuk } \\
\text { menghadapi dua atau lebih tuntutan } \\
\text { yang harus dipenuhi karyawan serta } \\
\text { mampu membantu karyawan } \\
\text { mempertahankan perasaan } \\
\text { menyenangkan dan positif yang } \\
\text { dimiliki karyawan terhadap } \\
\text { pekerjaannya yang kemudian akan } \\
\text { berpengaruh positif pula terhadap } \\
\text { kepuasan kerja karyawan (Nurendra } \\
\text { and Saraswati 2016). }\end{array}$ & $\begin{array}{l}\text { 1. Dapat membagi waktu kerja } \\
\text { dengan waktu untuk keluarga } \\
\text { 2. Dapat menggunakan waktu } \\
\text { istirahat dengan baik }\end{array}$ & Skala likert \\
\hline $\begin{array}{l}\text { Personality-Job } \\
\text { Fit }\end{array}$ & $\begin{array}{l}\text { Kesesuaian antara kepribadian yang } \\
\text { dimiliki karyawan dengan pekerjaan } \\
\text { yang dilakukannya (Etnaningtiyas } \\
\text { 2011). }\end{array}$ & $\begin{array}{l}\text { 1. Pengetahuan } \\
\text { 2. Kemampuan } \\
\text { 3. Keahlian }\end{array}$ & Skala likert \\
\hline Stres Kerja & $\begin{array}{l}\text { Kondisi yang muncul dari interaksi } \\
\text { personal dengan pekerjaan serta } \\
\text { dikarakteristikkan oleh perubahan } \\
\text { seseorang yang memaksa mereka } \\
\text { untuk menyimpang dari fungsi } \\
\text { normal mereka (Massie, Areros, and } \\
\text { Rumawas 2018). }\end{array}$ & $\begin{array}{l}\text { 1. Stressor Individu (beban kerja, } \\
\text { hubungan dalam bekerja). } \\
\text { 2. Stressor Organisasi (kebijakan } \\
\text { organisasi, proses yang terjadi } \\
\text { dalam organisasi). }\end{array}$ & Skala likert \\
\hline $\begin{array}{l}\text { Hubungan } \\
\text { Karyawan }\end{array}$ & $\begin{array}{l}\text { Upaya untuk meningkatkan kualitas } \\
\text { kerja sehingga dapat menjadi lebih } \\
\text { baik dan bagaimana manajemen dan } \\
\text { sumber daya manusia mempengaruhi } \\
\text { kualitas kerja (Ahmad and } \\
\text { Hermawan 2012). }\end{array}$ & $\begin{array}{l}\text { 1. Interaksi antar karyawan } \\
\text { 2. Bimbingan } \\
\text { 3. Disiplin }\end{array}$ & Skala likert \\
\hline Kompensasi & $\begin{array}{l}\text { Pengaturan seluruh pemberian balas } \\
\text { jasa karyawan baik dalam bentuk } \\
\text { langsung berupa uang maupun dalam } \\
\text { bentuk yang tidak langsung berupa } \\
\text { uang (Pratama 2015). }\end{array}$ & $\begin{array}{l}\text { 1. Jumlah gaji } \\
\text { 2. Jumlah komisi } \\
\text { 3. Jumlah bonus }\end{array}$ & Skala likert \\
\hline $\begin{array}{l}\text { Lingkungan } \\
\text { Kerja Fisik }\end{array}$ & $\begin{array}{l}\text { Segala sesuatu yang berada di sekitar } \\
\text { para pekerja yang dapat } \\
\text { mempengaruhi pekerja dalam } \\
\text { menjalankan tugas yang telah } \\
\text { dibebankan (Rahmawanti 2014). }\end{array}$ & $\begin{array}{l}\text { 1. Kenyamanan saat bekerja di } \\
\text { kantor } \\
\text { 2. Kenyamanan saat bekerja di } \\
\text { luar kantor } \\
\text { 3. Kenyamanan fasilitas }\end{array}$ & Skala likert \\
\hline Kepuasan Kerja & $\begin{array}{l}\text { Kondisi emosi yang senang yang } \\
\text { berasal dari penilaian pekerjaan atau } \\
\text { pengalaman kerja (Ramasari and } \\
\text { Wahyuningtyas 2014). }\end{array}$ & $\begin{array}{l}\text { 1. Kesempatan promosi } \\
\text { 2. Rekan kerja } \\
\text { 3. Atasan } \\
\text { 4. Pekerjaan yang dilakukan }\end{array}$ & Skala likert \\
\hline $\begin{array}{l}\text { Budaya } \\
\text { Organisasi }\end{array}$ & $\begin{array}{l}\text { Pola dari asumsi yang ditemukan, } \\
\text { diciptakan atau dikembangkan oleh } \\
\text { suatu kelompok tertentu dengan }\end{array}$ & $\begin{array}{l}\text { 1. Dukungan manajemen } \\
\text { 2. Toleransi terhadap konflik } \\
\text { 3. Inisiatif individu }\end{array}$ & Skala likert \\
\hline
\end{tabular}




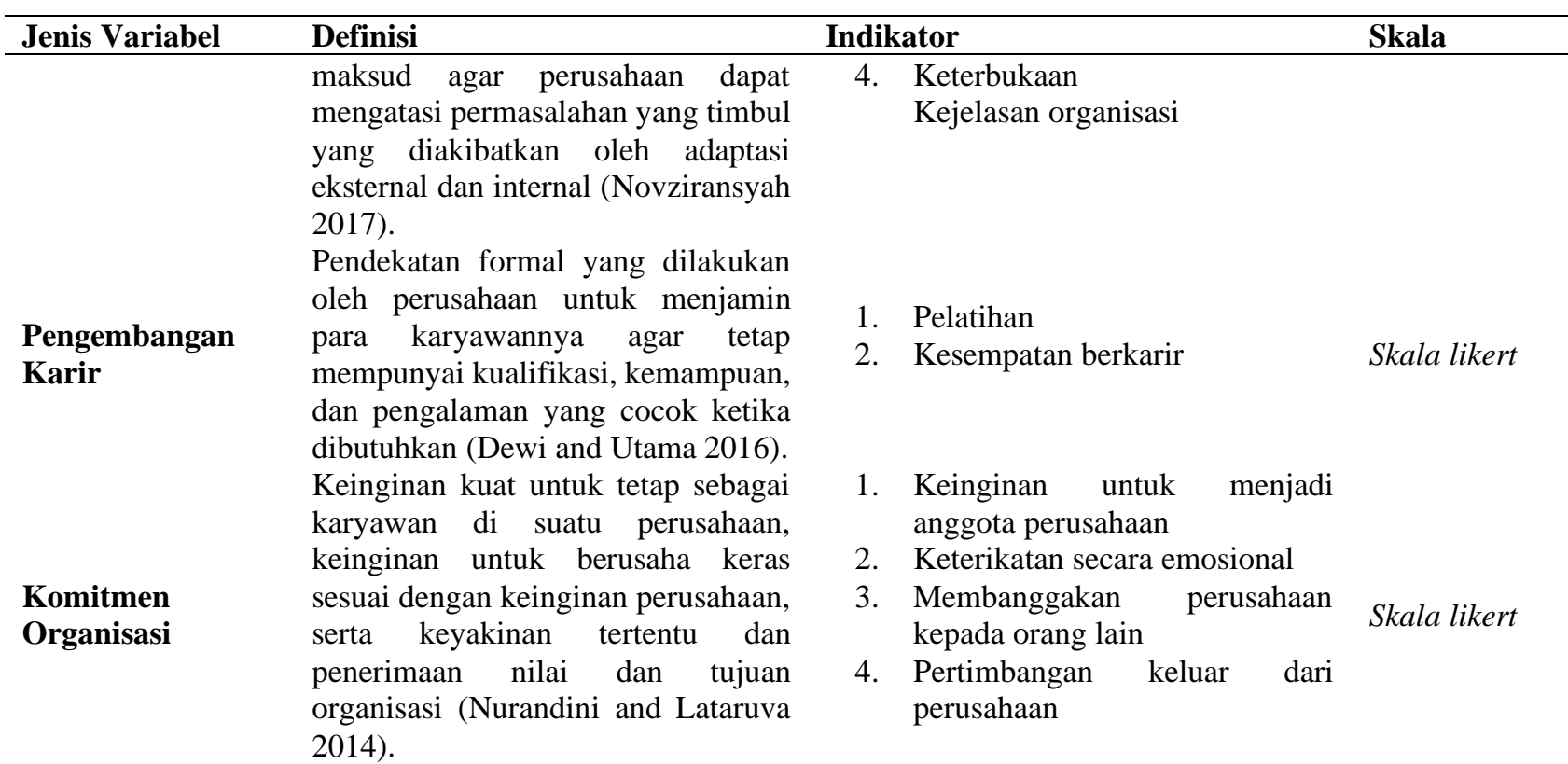

Populasi dalam penelitian ini adalah agent asuransi di PT AIA Cabang X Malang. Berdasarkan data yang didapatkan, jumlah agent pada PT AIA Cabang X Malang pada tahun 2019 sebanyak 202 orang. Responden minimal bekerja selama 3 bulan, disebabkan karena selama 3 bulan apabila agent tidak memenuhi target maka akan tervalidasi dari perusahaan. Penelitian ini menggunakan jumlah sampel yang dilakukan dengan sensus (sampel jenuh). Sumber data pada penelitian ini menggunakan data primer ini dikumpulkan melalui metode survey dengan menggunakan kuesioner. Metode pengumpulan data yang digunakan dalam penelitian ini adalah menggunakan metode survei secara online (webbased questionnaire) dan secara langsung kepada responden untuk mendapatkan data yang akan diolah peneliti. Penggunaan metode survei secara online dilakukan karena dapat lebih mudah dalam menyebar kuesioner dan jumlah responden yang didapatkan lebih banyak dan lebih cepat diterima oleh peneliti. Link kuesioner online akan disebar via media sosial, grup chat yang akan dibagikan kepada teman grup chat lainnya oleh responden terkait. Pertanyaan pada kuesioner akan menggunakan pertanyaan close-ended skala Likert lima poin. Penggunaan metode survei secara langsung diberikan kepada responden dengan meminta izin dan membuat janji terlebih dahulu. Penelitian ini dilaksanakan oleh peneliti sendiri dengan menandatangani perusahaan tersebut.

Penelitian ini juga melakukan uji validitas untuk mengukur sah atau valid tidaknya suatu kuesioner. Kriteria valid atau tidak adalah jika korelasi antar skor masing-masing butir pertanyaan dengan skor total memiliki tingkat signifikan di bawah 0,05 maka butir pertanyaan tersebut dikatakan valid, dan jika korelasi skor masing-masing butir pertanyaan dengan skor total memiliki tingkat signifikan di atas 0,05 maka butir pertanyaan tersebut tidak valid (Ghozali 2006). Selain itu dalam mengatasi keandalan data, akan dilakukan uji internal-consistent reliability yaitu mengukur dua atau lebih konsep yang sama pada waktu yang bersamaan. Selain itu, internal-consistent reliability juga dapat membandingkan untuk melihat tingkat kesetujuan responden. Hasil uji reliabilitas digunakan untuk mengetahui instrumen penelitian yang dipakai dapat digunakan berkali-kali pada waktu yang berbeda. Pengujian dilakukan dengan menggunakan teknik cronbach alpha. Suatu instrumen dikatakan tidak reliabel bila memiliki koefisien atau alpha sebesar; (1) <0,6 tidak reliabel (2) 0,6--0,7 acceptable (3) 0,7--0,8 baik (4) > 0,8 sangat baik (Ghozali 2006).

Teknik analisis dalam penelitian ini menggunakan CFA (Confirmatory Factor Analysis). CFA digunakan untuk menguji unidimensional, validitas dan reabilitas model pengukuran konstruk yang tidak dapat diukur langsung. Di dalam penelitian ini akan dilakukan analisis terkait dengan faktor-faktor yang mempengaruhi turnover intention agent di PT AIA Cabang X Malang. Menurut (Arikunto 2019) kriteria yang digunakan dalam pengujian ini yaitu :

1. Nilai t muatan faktornya (loading factor) lebih besar dari nilai kritis (atau $\geq 1,96$ atau untuk praktisnya $\geq 2$ ).

2. Muatan faktor standart (standardized loading factors) $\geq 0,70$.

3. Nilai construct realiability $(\mathrm{CR}) \geq 0,70$ dan nilai average variance extracted $(\mathrm{AVE}) \geq 0,50$.

\section{HASIL DAN PEMBAHASAN}

Berdasarkan hasil uji instrumen terkait validitas dan reliabilitas, diketahui bahwa seluruh item pernyataan adalah valid di mana seluruh item pernyataan pada masing-masing variabel memiliki angka koefisien korelasi yang lebih besar dari nilai kritik (r). Sehingga dapat disimpulkan bahwa instrumen penelitian yang digunakan adalah valid, karena terbukti bahwa nilai koefisien korelasi lebih besar dari nilai kritik pada tingkat kepercayaan 95\%. Dengan demikian kuesioner dalam penelitian ini dapat digunakan untuk menjelaskan faktor - faktor yang mempengaruhi turnover intention. Pada hasil uji reliabilitas, menunjukkan bahwa Cronbach's Alpha di atas 0,6. Dengan demikian dapat disimpulkan bahwa semua instrumen dalam penelitian ini meskipun dilakukan pengujian secara berulang-ulang dapat menghasilkan hasil yang sama sehingga dapat digunakan untuk menjelaskan faktor - faktor yang mempengaruhi turnover intention.

Berdasarkan hasil ringkasan nilai AVE dan Composite Reliability pada setiap variabel sebagai berikut 
Tabel 3. Ringkasan Nilai AVE, Composite Reliability dan Uji T

\begin{tabular}{ccccc}
\hline Item & AVE & Composite Reliability & t Hitung >1.96 & Keterangan \\
\hline Work life balance & 0.547 & 0.893 & 24.463 & Terkonfirmasi \\
Personality-job fit & 0.539 & 0.932 & 16.574 & Terkonfirmasi \\
Stres kerja & 0.606 & 0.914 & 8.880 & Terkonfirmasi \\
Hubungan karyawan & 0.543 & 0.934 & 24.329 & Terkonfirmasi \\
Kompensasi & 0.518 & 0.906 & 21.872 & Terkonfirmasi \\
Lingkungan kerja Fisik & 0.519 & 0.933 & 26.536 & Terkonfirmasi \\
Kepuasan kerja & 0.611 & 0.945 & 33.165 & Terkonfirmasi \\
Budaya organisasi & $\mathbf{0 . 6 2 9}$ & $\mathbf{0 . 9 5 9}$ & $\mathbf{3 7 . 0 8 1}$ & Terkonfirmasi \\
Pengembangan karir & $\mathbf{0 . 6 6 0}$ & 0.946 & 32.035 & Terkonfirmasi \\
Komitmen organisasi & 0.544 & $\mathbf{0 . 9 5 9}$ & $\mathbf{4 0 . 7 3 1}$ & Terkonfirmasi \\
\hline
\end{tabular}

Hasil kesimpulan data di atas seluruh variabel dapat mempengaruhi turnover intention agent. Melalui alat uji di atas menghasilkan nilai konsisten terlihat dari tabel AVE, nilai yang paling tinggi adalah 0.660 variabel pengembangan karier yang berarti mempunyai nilai paling tinggi berpengaruh terhadap turnover intention agent. Sedangkan composite reliability nilai tertingginya adalah 0.959 variabel budaya organisasi dan komitmen organisasi yang berarti mempunyai nilai paling tinggi berpengaruh terhadap turnover intention.

Berdasarkan hasil Tabel 2 di atas uji t > 1,96 adalah signifikan, maka disimpulkan semua variabel telah terkonfirmasi dan dapat digunakan dalam analisis faktor - faktor yang mempengarhui turnover intention agent di PT AIA Cabang X Malang. Nilai terbesar dalam setiap item variabel X menunjukkan bahwa item tersebut menunjang dan mendukung untuk pengaruh turnover intention agent. Jadi dapat disimpulkan bahwa 10 variabel yaitu work life balance, personality-job fit, stres kerja, hubungan karyawan, kompensasi, lingkungan kerja fisik, kepuasan kerja, budaya organisasi, pengembangan karir, dan komitmen organisasi menentukan turnover intention agent, karena hal ini dapat dilihat dari nilai-nilai diatas seluruh konstruk mampu menghasilkan nilai yang terkonfirmasi dan konsisten.

Berdasarkan hasil analisis dapat diketahui bahwa variabel work life balance, personality-job fit, stres kerja , hubungan karyawan, kompensasi, lingkungan kerja fisik, kepuasan kerja, budaya organisasi, pengembangan karir, dan komitmen organisasi memiliki indikator-indikator penyusun variabel yang menunjukan validitas dan reliabilitas yang baik. Hasil analisis dengan menggunakan model Confirmatory Factor Analysis (CFA) dapat diketahui nilai item masingmasing variabel yang paling mempengaruhi turnover intention agent di PT AIA Cabang X Malang, sebagai berikut:

Pada variabel work life balance, diketahui bahwa variabel work life balance terkonfirmasi mempengaruhi turnover intention agent. Menurut (Nurendra and Saraswati 2016) work life balance pada karyawan dapat membantu karyawan untuk menghadapi dua atau lebih tuntutan yang harus dipenuhi karyawan serta mampu membantu karyawan mempertahankan perasaan menyenangkan dan positif yang dimiliki karyawan terhadap pekerjaannya yang kemudian akan berpengaruh positif pula terhadap kepuasan kerja karyawan. Hasil rata-rata dari variabel ini sebesar 2,03 yang berarti tidak baik. Sebaiknya hasil pada variabel ini sebesar 3,4 - 4,19 atau baik, karena work life balance berpengaruh terhadap turnover intention agent .

Item pertanyaan pertama tentang sukar membagi waktu merupakan item dengan nilai distribusi frekuensi terkecil dikarenakan agent merasa untuk membagi waktu antara pekerjaan dan urusan pribadi bukanlah sesuatu yang susah karena pekerjaan yang dilakukan adalah pekerjaan yang fleksibel. Item pertanyaan keempat yaitu waktu kerja tersita untuk urusan pribadi merupakan item dengan nilai distribusi frekuensi terbesar. Kondisi ini dikarenakan banyak agent yang merasa mereka memiliki waktu yang cukup banyak untuk melakukan urusan pribadi dikarenakan mereka melakukan pekerjaan dengan fleksibel. Variabel ini harus diperhatikan oleh perusahaan karena jika agent merasa susah untuk membagi waktu antara pekerjaan dan juga urusan pribadi, mereka bisa saja berpikir untuk keluar dari pekerjaan saat ini. Pimpinan diharapkan dapat memberikan pelatihan atau pengarahan terhadap agent agar mereka dapat mengatur waktu kerja dan waktu pribadi mereka dengan baik sehingga nantinya mereka tidak merasakan beban pekerjaan.

Pada variabel personality-job fit, diketahui bahwa variabel personality-job fit terkonfirmasi mempengaruhi turnover intention agent. Menurut (Widyastuti and Ratnaningsih 2020), personality-job fit dinilai sebagai variabel penting yang harus diperhatikan oleh perusahaan karena berbagai dampak baik positif yang dihasilkan. Ketika perusahaan berhasil menciptakan kesesuaian antara tugas pekerjaan yang diberikan dengan karakteristik karyawannya maka performa pekerjaan karyawan akan meningkat, intensi karyawan untuk meninggalkan pekerjaan menurun serta dapat menghasilkan kepuasan kerja. Hasil rata-rata dari variabel ini adalah 4,01 yang artinya baik. Hasil ini sebaiknya dipertahankan atau ditingkatkan lagi agar agent merasakan kesenangan dalam bekerja.

Item pertanyaan keempat yaitu pekerjaan sesuai dengan keahlian merupakan item dengan nilai distribusi frekuensi terkecil. Kondisi ini dikarenakan agent merasa jika pekerjaan dan kemampuan yang mereka miliki tidak sesuai sehingga merasa tidak dapat melakukan pekerjaan secara maksimal. Item pertanyaan ketujuh yaitu pekerjaan sesuai dengan prinsip hidup merupakan item dengan nilai distribusi frekuensi terbesar. Kondisi ini dikarenakan agent merasa apa yang mereka kerjakan sekarang sesuai dengan prinsip hidup atau cita-cita yang mereka dambakan atau inginkan. Jika variabel ini tidak diperhatikan maka nantinya para agent akan merasakan kejenuhan dalam bekerja karena apa yang mereka kerjakan seharihari tidak sesuai dengan ketrampilan yang mereka miliki. Perusahaan harus memperhatikan agent, jangan sampai agent merasa kurang memiliki kesamaan antara pengetahuan yang dimiliki dengan bidang pekerjaan yang mereka lakukan, sehingga mereka tidak berpikir untuk keluar dari pekerjaan saat ini. 
Pada variabel stress kerja diketahui bahwa variabel stres kerja terkonfirmasi mempengaruhi turnover intention agent. Hal ini menunjukkan bahwa semakin tinggi stres kerja karyawan maka akan semakin tinggi pula tingkat turnover intention karyawan, sebaliknya semakin rendah stres kerja karyawan maka akan mengurangi tingkat turnover intention karyawan. Hasil rata-rata dari varibel ini adalah 1,96 yang berarti tidak baik. Sebaiknya variabel ini memiliki hasil ratarata 3,4-4,19 yang berarti baik.

Item pertanyaan pertama tentang beban kerja kurang tepat dengan kemampuan merupakan item dengan nilai distribusi frekuensi terkecil. Kondisi ini dikarenakan agent merasa bahwa beban kerja yang harus mereka terima sesuai dengan kemampuan yang mereka miliki sehingga mereka merasa kurang dalam stres bekerja. Item pertanyaan ketiga yaitu susah berkomunikasi dengan rekan kerja merupakan item dengan nilai distribusi frekuensi terbesar. Kondisi ini dikarenakan dalam bekerja dibidang asuransi dibutuhkan komunikasi yang baik ke rekan kerja, tetapi beberapa agent tidak dapat berkomunikasi dengan baik ke rekan kerja dikarenakan pada dasarnya mereka susah untuk melakukan komunikasi dengan orang yang belum dikenal lama. Pada variabel ini agent merasa tingkat stres kerja di perusahaan kurang tinggi, karena peran pimpinan yang memudahkan beban pekerjaan. Sebaiknya perusahaan mempertahankan tingkat stres kerja para agent dikarenakan stres kerja dapat membuat seseorang keluar dari perusahaan.

Pada variabel hubungan karyawan diketahui bahwa variabel hubungan karyawan terkonfirmasi mempengaruhi turnover intention agent. Menurut (Ahmad and Hermawan 2012) bahwa pemeliharaan hubungan karyawan dalam rangka keseluruhan proses manajemen sumber daya manusia berkisar pada pemikiran bahwa hubungan yang serasi dan harmonis antara manajemen dengan karyawan yang terdapat dalam perusahaan mutlak perlu ditumbuhkan, dijaga dan dipelihara demi kepentingan bersama dalam perusahaan. Kurang berhasilnya memelihara hubungan yang serasi dan harmonis ini akan merugikan banyak pihak dan tidak terbatas hanya pihak manajemen, tetapi pada hubungan antar karyawan juga. Hasil rata-rata 4,04 yang artinya baik dan harus dipertahankan.

Item pertanyaan kedua yaitu rekan kerja sangat aktif berbicara merupakan item dengan nilai distribusi frekuensi terkecil. Kondisi ini dikarenakan banyaknya agent yang telah senior sehingga mereka sering memberikan pembelajaran kepada agent junior. Item pertanyaan ketujuh yaitu menghormati hak-hak yang lainnya merupakan item dengan nilai distribusi frekuensi terbesar. Kondisi ini dikarenakan pimpinan menghargai hak-hak apa saja yang seharusnya didapatkan oleh agent, semisal fasilitas kerja. Pada variabel ini agent merasa jika hubungan antar karyawan tidak dijaga dengan baik maka untuk melakukan pekerjaan ini sangatlah susah, sehingga agent yang tidak memiliki hubungan yang baik dengan agent yang lain mereka berpikir untuk meninggalkan perusahaan. Sebaiknya pimpinan dapat memperhatikan para agent apakah ada kesenjangan di antara para agent, karena hal itu dapat berdampak tidak baik terhadap keberlanjutan kinerja agent.

Pada variabel kompensasi diketahui bahwa variabel kompensasi terkonfirmasi mempengaruhi turnover intention agent. Menurut (Putrianti 2014), bahwa ketidakpuasan terhadap kompensasi akan memicu perilaku karyawan yang negatif seperti kemangkiran dan kelesuan. Seringkali dikelompokkan dalam perilaku pengunduran diri atau disebut pula sebagai keinginan berhenti bekerja. Jika karyawan merasa belum puas terhadap kompensasi yang diberikan perusahaan, maka karyawan akan berperilaku negatif dan akan meningkatkan turnover intention. Hasil rata-rata dari variabel ini adalah 3,97 yang artinya baik, tetapi sebaiknya dapat ditingkatkan.

Item pertanyaan ketiga yaitu kompensasi memberikan kepastian masa depan merupakan item dengan nilai distribusi frekuensi terkecil. Kondisi ini dikarenakan agent telah paham dengan besaran kompensasi yang akan mereka dapatkan setiap bulannya. Item pertanyaan kedelapan yaitu pendapatan lebih baik dari tempat lain merupakan item dengan nilai distribusi frekuensi terbesar. Kondisi ini dikarenakan setiap bulannya agent mendapatkan komisi sebanyak 2 kali dalam sebulan dan jika dibandingkan dengan pekerjaan di beberapa tempat lain, kompensasi yang diterima oleh agent terbilang lebih besar dan lebih baik. Pada variabel ini agent merasa jika kompensasi yang diberikan tidak sesuai dengan perjanjian awal maka mereka akan meninggalkan perusahaan. Kondisi dimana agent pada saat ini masih merasakan jika kompensasi yang mereka dapatkan masih cukup dan sesuai. Jika nantinya terdapat agent yang mengeluh terhadap kompensasi yang diberikan sebaiknya pimpinan memberikan penjelasan dan pengarahan tentang perhitungan kompensasi di perusahaan, sehingga nantinya diharapkan agent dapat paham dan mengerti.

Pada variabel lingkungan kerja fisik diketahui bahwa variabel lingkungan kerja fisik terkonfirmasi mempengaruhi turnover intention agent. (Amalia 2018) mengatakan bahwa setiap karyawan selalu menginginkan lingkungan kerja yang menyenangkan, nyaman dan aman, sehingga suasana kerja yang nyaman, aman dan nyaman membuat para karyawan menjadi betah dan bertahan untuk bekerja di perusahaan. Tersedianya fasilitas kerja yang lengkap merupakan salah satu penunjang proses kelancaran dalam bekerja. Hal ini dimaksudkan agar karyawan dapat bekerja dengan optimal, dan membuat pekerjaan karyawan menjadi lancar sehingga karyawan tidak terbebani dengan pekerjaan. Pada akhirnya karyawan merasa mampu menyelesaikan semua tugas-tugas dan tetap ingin bekerja di perusahaan. Hasil rata-rata pada variabel ini yaitu 4,08 yang berarti baik dan harus dipertahankan atau ditingkatkan.

Item pertanyaan pertama tentang penerangan ruangan baik merupakan item dengan nilai distribusi frekuensi terkecil. Kondisi ini dikarenakan baiknya beberapa kondisi penerangan di beberapa ruangan baik dari segi lampu maupun pencahayaan alami. Item pertanyaan kesepuluh yaitu mendapat fasilitas di luar kantor merupakan item dengan nilai distribusi frekuensi terbesar. Kondisi ini dikarenakan agent mendapatkan fasilitas di luar kantor berupa pelayanan gratis mengenai followup ketika mengalami masalah sewaktu claim nasabah. Pada variabel ini agent merasa jika lingkungan kerja fisik di kantor sangatlah penting terutama ruangan kerja haruslah dirawat dengan baik, dikarenakan ruang kerja tempat untuk berkonsetrasi sehingga memerlukan ruang kerja yang baik dan memadahi. Kondisi lingkungan kerja fisik di perusahaan sudah sangat baik tetapi masih ada beberapa aspek yang harus di perhatikan seperti kelembapan ruangan 
dan beberapa tata kelola ruangan. Sebaiknya pimpinan melibatkan agent tentang desain dari lingkungan kerja fisik dan menanyakan fasilitas apa saja yang mereka butuhkan dan fasilitas apa saja yang telah ada tetapi harus diperbaiki.

Pada variabel kepuasan kerja diketahui bahwa variabel kepuasan kerja terkonfirmasi mempengaruhi turnover intention agent. Menurut (Sari 2015), kepuasan kerja merupakan hal yang bersifat individual karena setiap individu akan memiliki tingkat kepuasan yang berbeda-beda sesuai dengan nilai-nilai yang berlaku dalam diri mereka masing-masing. Karyawan akan menunjukkan komitmennya untuk tetap loyal pada perusahaan jika kepuasan kerja diperolehnya, sementara ketidakpuasan akan berpengaruh pada keluarnya karyawan, tingkat kehadiran yang rendah serta sikap negatif lainnya. Hasil rata-rata variabel ini adalah 4,13 yang berarti baik dan harus dipertahankan atau ditingkatkan oleh perusahaan.

Item pertanyaan ketiga yaitu pekerjaan sangat menyenangkan merupakan item dengan nilai distribusi frekuensi terbesar. Kondisi ini dikarenakan lingkungan kerja yang menyenangkan seperti teman kerja yang baik dan ramah, pimpinan yang suka memberika masukan dan jalan keluar dari masalah. Item pertanyaan kelima yaitu banyak peluang untuk maju merupakan item dengan nilai distribusi frekuensi terkecil. Kondisi ini dikarenakan tidak semua agent memiliki peluang yang sama untuk maju. Pada variabel ini agent merasa jika seorang pimpinan haruslah menjadi seorang teladan sehingga para agent merasa betah untuk bekerja dengan pemimpin yang bisa mengayomi bawahannya. Kepuasan kerja di perusahaan dapat terlihat bahwa agent melakukan pekerjaan mereka dengan senang dan tanpa ada paksaan dan agent menaati aturan-aturan yang ada di perusahaan. Jika terdapat agent yang merasakan ketidakpuasan terhadap kerjaan mereka, sebaiknya pimpinan diharapkan mampu memberikan pengarahan dan berdiskusi secara personal agar mengetahui masalah apa yang dihadapi dan nantinya pimpinan dapat memberikan solusi agar agent dapat bekerja dengan maksimal karena merasakan puas bekerja di perusahaan.

Pada variabel budaya organisasi diketahui bahwa variabel budaya organisasi terkonfirmasi mempengaruhi turnover intention agent. Hal ini menunjukkan bahwa karyawan dengan budaya organisasi yang tinggi akan memiliki keinginan untuk berpindah kerja yang lebih kecil. Upaya organisasi untuk penutunan perilaku karyawan, pada dasarnya adalah melakukan pemberdayaan sumber daya manusia atau karyawan seefektif mungkin, namun dengan mendasarinya pada budaya organisasi yang tepat. Hasil rata-rata pada variabel ini yaitu 4,02 yang artinya baik dan harus dipertahankan atau bahkan ditingkatkan.

Item pertanyaan keempat yaitu memiliki inisiatif untuk mengerjakan tugas merupakan item dengan nilai distribusi frekuensi terbesar. Kondisi ini dikarenakan para agent tidak perlu diperintahkan untuk melakukan tugas mereka dengan baik dan tepat waktu. Item pertanyaan kedelapan yaitu pimpinan memberi kebebasan untuk mengambil keputusan merupakan item dengan nilai distribusi frekuensi terkecil. Kondisi ini dikarenakan pimpinan terlalu mengatur apa yang dilakukan oleh agent sehingga mereka susah untuk mengambil keputusan sendiri. Pada variabel ini agent merasa untuk melakukan pekerjaan yang baik dan benar, pimpinan seharusnya memberikan penjelasan mengenai tujuan perusahaan dan juga target perusahaan maupun target agent, sehingga nantinya akan teringat oleh agent. Budaya organisasi terlihat sangat baik dimana terdapat waktu tertentu agent harus mengenakan baju perusahaan yang bertujuan untuk menumbuhkan rasa cinta agent terhadap perusahaan. Pimpinan juga memberikan contoh yang baik kepada agent sehingga agent dapat melihat dan mencontoh perilaku baik pimpinan.

Pada variabel pengembangan karir diketahui bahwa variabel pengembangan karir terkonfirmasi mempengaruhi turnover intention agent. Semakin tinggi kepercayaan karyawan terhadap pengembangan karir perusahaan maka kecenderungan mereka untuk meninggalkan perusahaan akan menjadi semakin kecil. Hasil rata-rata variabel ini yaitu 4,12 yang berarti baik dan harus dipertahankan atau ditingkatkan.

Item pertanyaan kedua yaitu agent yang menonjol lebih prioritas untuk promosi merupakan item dengan nilai distribusi frekuensi terkecil. Kondisi ini dikarenakan tidak semua agent yang menonjol lebih mudah untuk promosi, karena ada beberapa syarat untuk mendapatkan promosi. Item pertanyaan kesembilan yaitu memiliki gaya pelatihan berbeda setiap waktu merupakan item dengan nilai distribusi frekuensi terbesar. Kondisi ini dikarenakan pada setiap beberapa waktu dan terjadwal, pelatihan yang dilakukan menerapkan konsep dan tema yang berbeda untuk menambah wawasan agent dan agar agent tidak merasa bosan. Pada variabel ini agent merasa jika pengembangan karir di kantor sangatlah penting terutama untuk terjadinya promosi pekerjaan. Mentor diharapkan dapat mendorong dan membantu para agent untuk selalu bekerja semaksimal mungkin sehingga memberikan hasil yang maksimal untuk perusahaan. Jika dalam rentan waktu kerja yang lama agent tidak merasakan pengembangan karir yang berdampak terhadap dirinya, maka bisa saja agent berpikir untuk keluar dari perusahaan.

Pada variabel komitmen organisasi diketahui bahwa variabel komitmen organisasi terkonfirmasi mempengaruhi turnover intention agent. Menurut (Sutanto and Gunawan 2013), komitmen organisasi berkaitan dengan keinginan karyawan yang tinggi untuk berbagi dan berkorban bagi perusahaan. Pentingnya komitmen organisasi bagi suatu perusahaan disebabkan karena tanpa komitmen organisasi, perusahaan sulit untuk mendapatkan partisipasi aktif dan mendalam dari karyawan. Karyawan yang memiliki komitmen organisasi yang tinggi memberikan kontribusi besar kepada perusahaan karena mereka mau bekerja semaksimal mungkin dan berperilaku baik dalam mencapai tujuan perusahaan. Semakin besar komitmen organisasi maka akan semakin kecil angka turnover. Hasil rata-rata pada variabel ini yaitu 4,00 yang berarti baik dan diharapkan dapat mencapai hasil 5,00 atau sangat baik.

Item pertanyaan ketujuh yaitu tetap bekerja pada perusahaan merupakan item dengan nilai distribusi frekuensi terbesar. Kondisi ini dikarenakan rasa kekeluargaan dan kedekatan agent sudah besar terhadap perusahaan. Item pertanyaan kedua puluh yaitu mungkin akan meninggalkan perusahaan dalam waktu dekat merupakan item dengan nilai distribusi frekuensi terkecil. Kondisi ini dikarenakan sedikitnya agent yang berpikir untuk meninggalkan perusahaan hanya dikarenakan beberapa alasan yang kurang jelas. Pada variabel ini agent merasa jika perusahaan memiliki komitmen 
yang besar dan baik dalam persaingan dan juga dalam memberdayakan sumber daya manusia, maka para agent merasa bersalah jika harus keluar dari perusahaan. Agent merasakan bahwa komitmen organisasi itu penting ditanam di dalam diri, karena jika dalam pekerjaan kita tidak berkomitmen dalam pekerjaan dan tidak berkomitmen untuk perusahaan, maka pada saatnya agent akan merasakan kejenuhan dan akan berpikir untuk keluar dari perusahaan. Pimpinan sebaiknya diharapkan dapat menumbuhkan rasa komitmen agent terhadap perusahaan dengan memperhatikan kesembilan variabel di atas, karena kesembilan variabel di atas berperan penting terhadap komitmen agent.

\section{KESIMPULAN}

Tujuan dari penelitian ini adalah untuk mengetahui faktor-faktor apa saja yang mempengaruhi turnover intention agent di PT AIA Cabang X Malang. Dari hasil penelitian ini dapat ditarik beberapa kesimpulan antara lain seluruh variabel work life balance, personality-job fit, stres kerja, hubungan karyawan, kompensasi, lingkungan kerja fisik, kepuasan kerja, pengembangan karir, budaya organisasi, dan komitmen organisasi dapat mempengaruhi turnover intention agent di PT AIA Cabang X Malang. Selain itu faktor yang memiliki kontribusi yang paling besar dalam mempengaruhi turnover intention agent adalah variabel komitmen organisasi, variabel budaya organisasi dan yang terakhir variabel kepuasan kerja. Adapun faktor yang memiliki kontribusi yang kecil dalam mempengaruhi turnover intention agent adalah stres kerja dan personality-job fit.

Peneliti menyarankan perusahaan dapat memperhatikan 10 faktor yang sudah diteliti ini untuk meningkatkan sumber daya manusia, terutama pada faktor komitmen organisasi dan budaya organisasi dikarenakan rata-rata para agent lebih memilih untuk keluar dari perusahaan dikarenakan komitmen organisasi dan budaya organisasi yang kurang baik. Peneliti juga menyarankan pada penelitian selanjutnya diharapkan dapat mencakup wilayah yang lebih luas yaitu seluruh Jawa Timur dengan memberikan minimal jumlah responden di masing-masing wilayah serta tidak hanya terbatas pada populasi satu perusahaan asuransi tetapi bisa ke beberapa perusahaan asuransi.

\section{UCAPAN TERIMAKASIH}

Terima kasih disampaikan kepada pihak LPPM Universitas Ma Chung yang telah mendukung terlaksananya penelitian ini.

\section{DAFTAR PUSTAKA}

Ahmad, Nur, and Didik Hermawan. 2012. “Analisis Pengaruh Hubungan Karyawan (Employee Relation) Terhadap Kepuasan Kerja Karyawan PT. Menara Kartika Buana Di Karanganyar."

Amalia, Monica Dwi. 2018. "Pengaruh Kepuasan Kerja Dan Lingkungan Kerja Terhadap Turnover Intention Karyawan Di PT Mirota Kampus Yogyakarta.” Jurnal Manajemen Bisnis Indonesia (JMBI) 7(1):107-17.

Arikunto, Suharsimi. 2019. "Prosedur Penelitian Suatu Pendekatan Praktik."

Darmadi, Hamid. 2013. "Metode Penelitian Pendidikan Dan Sosial." Bandung: Alfabeta.

Dewi, Ni Luh Putu Ariesta Angga, and I. Wayan Mudiartha Utama. 2016. "Pengaruh Pengembangan Karir Terhadap Kinerja Karyawan Melalui Mediasi Motivasi Kerja Pada Karya Mas Art Gallery.” E-Jurnal Manajemen 5(9).

Etnaningtiyas, Aningeti Prihandini. 2011. "Faktor-Faktor Yang Mempengaruhi Intensi Turnover Pada Karyawan PT: Alenatex Bandung."

Firdaus, Ahmad. 2017. "Faktor-Faktor Yang Mempengaruhi Turnover Intention (Studi Pada Karyawan Perusahaan Jasa Multi Finance Di Kota Jambi)." Ekonomis: Journal of Economics and Business 1(1):1-9.

Ghozali, Imam. 2006. Aplikasi Analisis Multivariate Dengan Program SPSS. Badan Penerbit Universitas Diponegoro.

Indonesia, Michael Page. n.d. "Employess Intention Report: Indonesia." 2015. Retrieved October 10,2018 (http://www.michaelpage.co.id/sites/michaelpage.co.id/files/2015_IDMP_EMPLOYEE_INTENTIONS_FINAL.pdf).

Lisan, Wilson. 2016. "Analisis Pengaruh Turnover Karyawan, Motivasi, Dan Pengayaan Pekerjaan, Terhadap Kepuasan Kerja Karyawan Pada PT. Enseval Megatrading Tbk Manado.” Jurnal Berkala Ilmiah Efisiensi 16(3).

Mangkunegara, Anwar Prabu, and Anwar Prabu. 2009. "Manajemen Sumber Daya Manusia." Bandung: PT. Remaja Rosdakarya.

Massie, Rachel N., William A. Areros, and Wehelmina Rumawas. 2018. "Pengaruh Stres Kerja Terhadap Kinerja Karyawan Pada Kantor Pengelola It Center Manado.” JURNAL ADMINISTRASI BISNIS (JAB) 6(002).

Novziransyah, Nanda. 2017. "Pengaruh Budaya Organisasi Terhadap Kinerja Karyawan PT. PLN (Persero) Kantor Wilayah Sumatera Utara Medan.” JUMANTIK (Jurnal Ilmiah Penelitian Kesehatan) 2(1):14-25.

Nurandini, Arina, and Eisha Lataruva. 2014. "Analisis Pengaruh Komitmen Organisasi Terhadap Kinerja Karyawan (Studi Pada Pegawai Perum PERUMNAS Jakarta).”

Nurendra, Annisaa Miranty, and Mega Putri Saraswati. 2016. "Model Peranan Work Life Balance, Stres Kerja Dan Kepuasan Kerja Pada Karyawan.” Humanitas: Jurnal Psikologi Indonesia 13(2):84-94.

Pratama, Stefanus Andi. 2015. "Pengaruh Kompensasi Terhadap Kinerja Karyawan (Studi Pada Karyawan PT. Asuransi Jiwasraya Persero Regional Office Malang)." Jurnal Administrasi Bisnis 25(1).

Putrianti, Arin Dewi. 2014. "Pengaruh Kompensasi Dan Motivasi Kerja Terhadap Turnover Intention (Studi Pada Karyawan PT. TIKI Jalur Nugraha Ekakurir Pusat Malang).” Jurnal Administrasi Bisnis 12(2).

Rahmawanti, Nela Pima. 2014. "Pengaruh Lingkungan Kerja Terhadap Kinerja Karyawan (Studi Pada Karyawan Kantor Pelayanan Pajak Pratama Malang Utara).” Jurnal Administrasi Bisnis 8(2).

Ramasari, Putri Febrian, and Ratri Wahyuningtyas. 2014. "Analisis Faktor-Faktor Yang Mempengaruhi Turnover Intention Karyawan Outsourcing Kisel Di PT. Telkomsel Regional Jawa Barat.” EProceedings of Management 1(3).

Sari, Nita Ratna. 2015. "Pengaruh Kepuasan Kerja Terhadap Turnover Intention (Studi Pada AJB Bumiputera 1912 Kantor Wilayah 
Ekonomi, Keuangan, Investasi dan Syariah (EKUITAS)

Vol 2, No 2, Februari 2021, Hal 177-186

ISSN 2685-869X (media online)

DOI: 10.47065/ekuitas.v2i2.667

Jatim II/Malang).” Jurnal Administrasi Bisnis 27(1).

Sutanto, Eddy Madiono, and Carin Gunawan. 2013. "Kepuasan Kerja, Komitmen Organisasional Dan Turnover Intentions.” Jurnal Mitra Ekonomi Dan Manajemen Bisnis 4(1):76-88.

Sutrisno, Edy. 2019. "Manajemen Sumber Daya Manusia."

Tedjo, Putri Fortunata. 2016. “Analisis Faktor-Faktor Turnover Intentions Di CV. Sekawan Cosmetics Sidoarjo.” Agora 4(2):238-43. Wahyuni, Ana Sri, Yulvi Zaika, and Ruslin Anwar. 2015. “Analisis Faktor-Faktor Yang Mempengaruhi Turnover Intention (Keinginan Berpindah) Karyawan Pada Perusahan Jasa Konstruksi.” Rekayasa Sipil 8(2):89-95.

Widyastuti, Titis, and Ika Zenita Ratnaningsih. 2020. "Hubungan Antara Person Job-Fit Dengan Kepuasan Kerja Pada Karyawan Kantor Pusat Bank Jateng Semarang.” Empati 7(3):907-13. 